\title{
The relationship of the plant protection and the applied technology in the integrated apple production
}

\author{
Csihon, Á., Holb, I. \& Gonda, I. \\ University of Debrecen, Faculty of Agriculture, Institute of Horticulture, \\ 138. Böszörményi str., Debrecen, H-4032, Hungary
}

Summary: The indirect elements of the integrated plant protection can influence the effectiveness of the chemical control, however their significance are often extenuated. The characteristic of the plants are almost completely disregarded at the protection decisions. The condition can determinate basically the rate of the damages caused by the pests. The plant in good conditional state has higher tolerance and lower susceptibility against the pests. With the optimal general and annual condition we can establish and maintain the harmony between the growth and the bearing, what is the basis of effective plant protection.

Key words: integrated plant protection, indirect elements, general condition, annual condition

\section{Introduction}

The direct elements of the integrated plant protections beyond the chemicals are mechanical, biological and biotechnical elements. The indirect elements, which have got significant role in the effectiveness of the protection, often handled just peripherally and in the most cases of the control decisions it is not suggested to exploit of these opportunities. In the majority cases the central issues of the plant protection are the relationship of the pests and the pesticides, the spearing of the beneficial organisms, the control decisions with the adequate chemicals (green or yellow) based on prognosis, the rotation of the pesticides, and so on. The peculiarities of the plants are almost completely disregarded or just the relationship of the phonological phase and the pests means the "role" of the plant regarding the determination of the time and the method of the protection.

The integrated conception and the practise carry more contents, than we describe it here. The indirect elements which focuses on the plant and its current state, influence highly the effectiveness of the chemical protections. Such elements are considered the size, the shape, the structural construction, the physiological characteristics of the plants, and its differences depending on the vintage and the bearing state, in addition the growing and bearing habitats determinated by the external environment, finally the plant condition.

\section{The condition of the apple trees}

The condition is an essential factor of the scale and the rate of the damage caused by the pests. The plant in good conditional state has higher resistance against the pests and the susceptibility is smaller than in the case of its extremes.

The condition of the apple trees are often related with the growing habitats, the length of the shoots, the colour of the foliage and the yields. Zatykó's (1980) phrasing is the most expressive and the most common approach as the follows: "the tree is in optimal condition when the vegetation activity and the assimilation supply are in harmonious balance with each other" (Figure 1). This state equals with the bearing balance of the tree, that is the squared high yields with good quality from year to year and the harmonized state of the shoot elongation. Whether one side or the other side is extremely dominant, it means unambiguously weaker condition. Zatykó (1980) divided the condition to two groups, as general and annual condition.

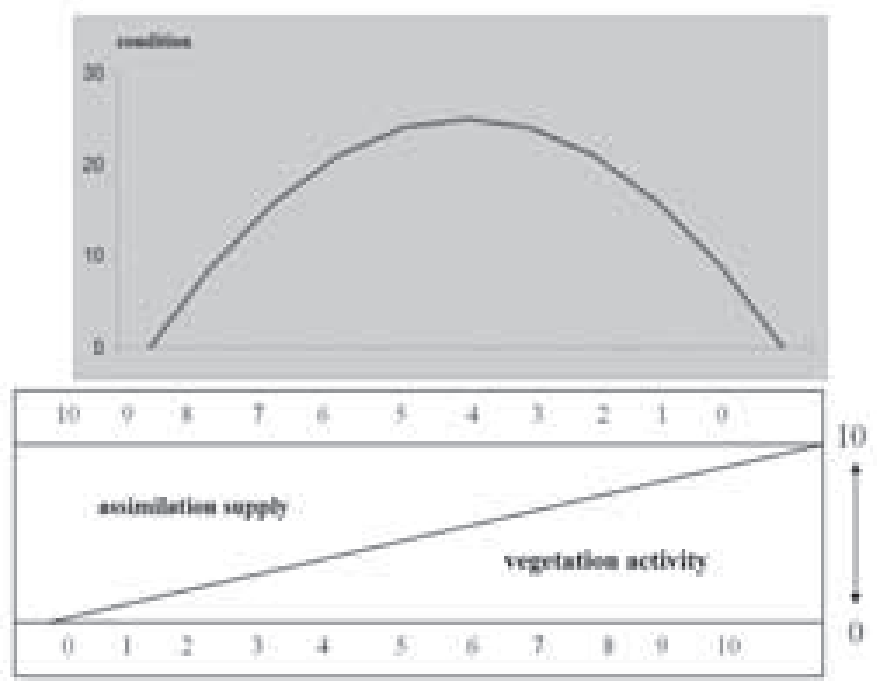

Figure 1. Optimal condition = harmony between the assimilation supply and the vegetation activity (Zatykó, 1980) 


\section{General conditions}

The general condition means the ecological factors (location, exposure, climate and meteorological particularities, etc.) and the soil properties (structure, thickness of tilth, nutrient and water supply capacity, etc.). We rate the elements of the training system (rootstock, variety, planting design, canopy) to the general condition as well, as the factors what can influence the growing and the bearing of the orchard in its all life. So the biological bases also belong to the general condition, what must harmonize with the ecological conditions for the sake of the improvement of the adaptability and the tolerance. The perfect adaptability can help significantly the success of the plant protection. The general condition can determinate also the growing and the bearing properties of the trees in the whole life of the orchard, and also the relationship with the plant protection.

In the view of the plant protection the creation of the optimal general condition is considered as the strategy of the plant protection that is the determinative factor of its possibility to prevail in long term. Therefore after the planting every single factor cannot be changed. However in some cases we have possibilities to prevent or reduce certain damages by building protection systems (hail nets, rain protection system, frost protection systems, etc.). Although the application of these systems cannot compensate the failures of the production which caused by the badly chosen production sites.

\section{Annual conditions}

The annual condition contrary to the general condition can be considered as the tactical element of the plant protection, which changes annually, and influenced by external effects.

The annual condition can be controlled by the harmonisation of the bearing processes and the obligate changing of the technological elements. So the previous one (general condition) influences the success of the plant protection in long term and the latter one (annual condition) does it in short term, corresponding with the vintage effect.

The annual condition is related with the meteorological peculiarities of the year and the bearing phase (excessive, moderate or harmonic yields).

Most of all the moderation of the excessive vegetative growth is needed. The main effect of the too vigorous trees is the reduction of the annual yield (decreasing the fruit setting, increasing the June dropping), but there are further problems, such late terminal bud closing, prolonged growth, large number of loose textured peak of shoots (higher susceptibility), shaded canopy, humid, airless, sunlight poor conditions and limited spray penetration and covering.

In the case of generative dominance the reduction of the leaf area and leaf function means the problem which is correlated with the fruit load. In the case of overburden the rate of the deprecation with the quality decreasing caused by the pests and the chance of the biannual bearing is much larger. The sustained foliage damage at this time can induce more fruit failure for the next year.
The biological basis with higher yields and the better general condition together means the increasing of the number and the frequency of the biannual bearing. It unambiguously appears in plant protection problems, as both in the years with spontaneously high yield, and both in the years with low yields, the weakening of the condition occurs.

Further we detail the role of the elements of the general and the annual condition in the plant protection, its effects and the opportunities of the influence. We don't talk about the well known relationship of the ecological factors (temperature, precipitation, humidity, etc.) and the plant protection. However we employ with the elements of the training system, as the indirect effect of these are relevant in the success of the plant protection.

\section{The relationship of the general condition and the plant protection}

\section{Planting material}

We deal with the planting material, because its quality can determinate in an orchard the equal or different size, the structure and growing habitats of the formed tree in long term period.

The scions, that is the uniformity, homogeneity of the planting material is a critically relevant factor of the later homogeneous, uniformity what facilities significantly the success of the plant protection. Unfortunately, the biggest part of the home nurseries due to different reasons are not able to produce scions with high biological value and higher certification (one year old tree with branches, Knipp tree), which doesn't require any pruning correction intervention after the planting. These kind of Hungarian scions are more heterogeneous and are on different development stage level, what require shaping pruning interventions in different measure and way. The trees planted with such kind of scions neither don't reach later the homogenous uniform state. Unfortunately in most of the years it occurs often, that there are shoots on the tree with closed terminal bud and there are shoots which are still growing in the same time. The same can also appear in one tree with extreme scale. This is unfavourable in the view of the plant protection. One group has no or less susceptible, the other on the contrary is very susceptible to the infection. The securing of the required same spray covering is an unnecessary waste in one's group, and at the other group is not sufficient. Accordingly the time period of the susceptibility is closely related with the dynamics of the shoot elongation (the intensity of the growing and its duration, and when terminal bud closing).

\section{Rootstock, planting design, canopy}

In the last decades the changes of the training system showed the intensity growing efforts, what resulted in higher 
planting density and smaller trees. Nowadays the most common used rootstocks are the dwarfing M26 and the very dwarfing M9 in the intensive orchards, which are prospective for the future as well. These rootstocks are the key factors of the smaller planting design and crown size, what are essentials to keep the tress in the available space.

Probably the 0,7-1,2 $\mathrm{m}$ width super spindle and slender spindle and the $1,5-3 \mathrm{~m}$ width free spindle canopies will be the most expansively used crown forms in short and long term. These smaller canopies cause better spray-, sunlight-, and air penetration, which appear in the increase of the effectiveness of the plant protection. It can be stated, that these orchards won't become more intensive in short and in medium term. The occurrence difference among the orchards can be just the margin of high of the trees. This kind of homogenization of the apple orchards can increase the possibilities of the plant protection unambiguously.

The shape, the spatial order and structure of the intensive canopies stood on more moderate and more productive rootstocks is a key factor in itself to harmonize the growing. The uniform illumination has got equalization effect on the growth in the external and the internal parts, and on the lower and on the higher parts. Besides it is also essential, that the uniformity of the trees in an orchard must prevail in the growing peculiarities (dynamics of shoot elongation, the closing time of the terminal bud, etc.), what can be achieved with the above mentioned homogeneity of the planting material.

Notwithstanding it is evident, the annual, miner extremes of the growing and the bearing can be mitigated by technological interventions with harmonizing effects.

\section{Applied varieties}

Regarding the produced varieties there are bigger differences in the vegetative growth, in the habit and the structure of the canopy, in the ramification ability, in the necessity of the pruning, in the time when the terminal bud closing, that is in the rate of the spray covering (plants grow out from under the spray or the spray attenuates in the plant), than in the resistant ability coded by genetically against the pests.

The number of the produced varieties and the richness of the varieties of the last decades decreased to some widespread varieties and sports: Gala sports, Jonagold sports, Red Delicious sports, Golden Delicious sports, Idared, Pinova, Topaz and Braeburn. There are not significant or just smallscale differences among the majority of the produced varieties regarding the genetically coded resistance or tolerance ability. So these differences appear just in small compass in the practice of the protection against the causative agents and pests. Among the varieties only the Topaz has resistant ability against the causative agents, what makes unnecessary the protection against of these.

The new resistant varieties selected even in the previous decades, even in the recent years, didn't get or didn't have the chance to get into the group of the widespread produced varieties used for fresh consumption. Namely these varieties are not competitive with their nutritional and consumer values, comparing with the above mentioned, inland produced varieties. As we know the resistant varieties are hybrids, and the fruits of the successor generation carry both the resistant genes, both the negative peculiarities of the one's parent what appear also in the taste. These negatives at best are just moderating in the successor generations of the cross-combinations of the high quality varieties, but doesn't appear totally. Also the Topaz variety produced in home orchards for fresh consumption has still such high acid level at the time of the harvest, what makes it possible to eat just after more monthes storage, when the acid content reduces. Of course the members of „Re"-sort from Germany are variable regarding both the appearance, both the nutritional values, but according to relevant professional and consumer opinions none of them will compete with the sort of most widespread ,world varieties" due to the latter.

It is likely that in short term surely, in the medium term supposedly we can't expect with the lunge of the resistant varieties with high nutritional values, therefore the change of the practice of the plant protection will not take place.

\section{The contexts of the annual condition and the plant protection}

\section{Phytotechnical (plant cultivation) operations influencing directly the annual condition}

- Changing the position of the shoots (bending down) toward the horizontal to control the excessive vegetative growth, to advance the closing time of the terminal bud, and to enhance the bearing.

- Winter pruning: to control the budload, to maintain the harmony between the short and long spurs, to avoid the extreme shoot elongation and to ensure the airy canopy structure.

- Summer pruning: to ensure the optimal leaf/fruit ratio, that is the ,correction" of the foliage to the number of the fruit, to the rate of the fruit load.

- Fruit thinning: to ensure the optimal fruit/leaf ratio, that is the correction of the number of the fruits to the foliage, to the number of the leaves for the sake of the expected fruit size and for the better bearing conditions in the next years. Further goals are making the internal parts more airy, to eliminate the hanging down parts and the fruit touching, and reduce the moth damage.

- Ringing interventions: to prepare semilunar rings on different height at the opposite sites, to prepare transverse bark rings on the trunk, which weakens the growth for the all tree as a result of the assimilate piling.

- Root pruning: to weaken the growth for the all tree as removing a part of the root. 


\section{Technological operations influencing indirectly the annual condition}

\section{Floor management}

In the case of vintages with excessive shoot elongation (moderate fruit load) or/and abundant precipitation we can reduce the growth temporary or permanently with the leaving of the weeds in the orchard. We can count with the same effect if we reduce the frequency of the mechanical mowing in the weeded rows.

It can be necessary to make soil loosening with knifes or air injection to compensate the growth weakening effect of the soil compaction.

\section{Nutrient management}

It can be practical to avoid the application of the nitrogen fertilizer in the years when we expect vigorous trees or just use them in the early period (February) to moderate the excessive shoot elongation.

It is advisable to apply the nitrogen fertilizer in late spring (during or after flowering) when we count with high yield and weaker growth to enhance the shoot elongation.

\section{Irrigation}

In the case of too strong shoot elongation it is practical to not irrigate temporary or permanently to promote the earlier terminal bud closing.

\section{The contexts of the general and the annual condition}

The infection of the plant can be occurred anyway despite the good general condition of the trees. However, if this couple with the weakening of the annual condition (growing and bearing extremes) the losses can became more significant. The rate of the damage can be reduced by the improvement of the annual condition and by keeping this on high level, despite the huge infection risk. We have to seek after the optimal condition with the all elements of the technology during the whole vegetation period that is we have to be ready for the application of the fast interventions and changes. The industrialisation of the fruit producing, the development of the technology, the more possibility for the automated interventions, none of them can't be without the thinking people. It is necessary to know better the plant, to determinate its visual and measurable changes and not least to explain of this. The adaptation to the changes and taking account of these can facilitate the more effective protection against the pests.

The most important challenges affecting the success of the plant protection of the Hungarian apple production
The solving of the next critical important tasks can help the more effective utilization and payback of the upcoming EU subsidies:

- Ensure the optimal production site (optimal general condition)

- Secure the development, homogeneous planting material (optimal general condition)

- Ensure the training systems harmonizing with the production site (optimal general condition)

- Applied technology with high development technological elements (optimal annual condition)

- Secure the protection against the weather extremes (optimal general and annual condition)

- Increased knowledge of the task plant (optimal, general and annual condition and creating the better adaptation ability to these factors)

In the future for the sake of the successful protection against the pest and for the possibility to utilize the „standby" technological interventions it is particularly important to know better the task plant, the pests and the beneficial organisms. Of course the continuous improvement of the chemical agents or active substances and the spraying techniques will stay also relevant.

\section{Acknowledgements}

The study was partly supported by the Hungarian Scientific Research Fund (OTKA K108333). This research was partly supported by the European Union and the State of Hungary, co-financed by the European Social Fund in the framework of TÁMOP-4.2.4.A/ 2-11/1-2012-0001 'National Excellence Program' under the project number: A2-SZJ-TOK-13-0061.

\section{References}

Csihon, Á. (2013): Kutatás felsőfokon. Kertészet és Szőlészet. 67. (37): 17-19. p.

Gonda, I. (1993): A fitotechnikai műveletek szerepe az alma integrált termesztés-technológiájában. Integrált termesztés a kertészetben 14: 72-78.

Gonda, I. (1994): A növényápolás szerepe. Kertészet és Szőlészet. 43. (6): 18-19.

Gonda, I. (2005): Az ökológiai növényvédelem közvetett elemei. [In: A gyümölcsösök és a szőlő ökológiai növényvédelme.] Szerk. Holb I. Mezőgazda Kiadó. Budapest. 340. 34-46. p.

Gonda, I., Fülep, I. (2011): Az almatermesztés technológiája. Debreceni Egyetem AGTC Kutatási és Fejlesztési Intézet, Gonda István Betéti Társaság, F. N. Fruit Kft. 260. p.

Gyúró, F. (1990): Gyümölcstermesztés. Mezőgazdasági Kiadó. 299. p.

Pethő, F. (1984): Alma. Mezőgazdasági Kiadó. Budapest. 677. p.

Zatykó, I. (1980): A gyümölcskötődés környezeti és agrotechnikai tényezői. [In: Gyümölcsfajták virágzásbiológiája és termékenyülése.] Szerk. Nyéki J. Mezőgazdasági Kiadó. Budapest. 138-150. p. 